\title{
Verification of a QTL on BTA1 for temperament in German Simmental and German Angus calves (Short Communication)
}

\author{
KRISTINA GLENSKE'1, HORST BRANDT'1, EVA-MARIA PRINZENBERG', MATTHIAS GAULY² \\ and GEORG ERHARDT ${ }^{1}$
}

'Department of Animal Breeding and Genetics, Justus-Liebig-University of Giessen, Giessen, Germany, ${ }^{2}$ Department of Animal Science, Georg-August-University of Göttingen, Göttingen, Germany

\begin{abstract}
A QTL on BTA1 near BMS574 was described for temperament in cattle. Eight German Simmental and six German Angus half sib families with all together 962 calves born in four consecutive years were used to verify the importance of this QTL. BMS574 and four flanking microsatellites (INRA117, DIK634, BMS4020 and DIK4957) were used in the study. Microsatellite INRA117 was monomorphic in both breeds and replaced. The number of alleles varied from two to 16 within breeds. Allele frequencies differed between the breeds and ranged from less than one percent to $99 \%$. All calves have been tested and scored for their behaviour in three different tests (tethering test, weighing test, separation- and restraint test). In addition, in German Simmental the status of polledness, horned or scurs respectively was recorded. A variance analysis separated by breeds was conducted for all microsatellites and the scores. The allele 169 of BMS1928 showed a significant effect on the score during weighing in German Simmental. Effects of BMS574 approached P-values near the $5 \%$-level in both breeds. So the study confirmed the importance of the proximal region of BTA1 in genetic background of behaviour in suckler cow calves.
\end{abstract}

Keywords: BTA1, microsatellites, temperament, polledness, beef cattle, calves

\section{Zusammenfassung}

\section{Bestätigung eines QTL auf BTA1 für Temperament bei Kälbern der Rassen Deutsches Fleckvieh und Deutsche Angus (Kurzmitteilung)}

Auf BTA1 bei BMS574 wurde ein QTL für Temperament bei Rindern beschrieben. Zur Bestätigung dieses QTL wurden acht Deutsches Fleckvieh und sechs Deutsche Angus Halbgeschwisterfamilien mit insgesamt 962 Kälbern, die in vier aufeinanderfolgenden Jahren geboren wurden, untersucht. BMS574 und vier flankierende Mikrosatelliten (INRA117, DIK634, BMS4020 and DIK4957) wurden analysiert. INRA117 stellte sich als monomorph heraus und wurde ersetzt. Die Anzahl der Allele je Mikrosatellit variierte zwischen zwei und 16 zwischen den Rassen und die Allelfrequenzen reichten von weniger $1 \%$ bis $99 \%$. Alle Kälber durchliefen drei verschiedene Verhaltenstests (Anbindetest, Wiegetest, Separier- und Rückhaltetest) mit entsprechenden Bewertungen in Form von scores. Zusätzlich wurde bei dem Deutschen Fleckvieh noch der Hornstatus mit erfasst und in die Analyse einbezogen. Statistisch wurde eine nach Rassen getrennte Varianzanalyse durchgeführt. Das Allel 169 von BMS1928 hatte 
einen signifikanten Effekt auf den Score während des Wiegens bei Deutschem Fleckvieh. BMS574 zeigte Effekte nahe der 5\%-Signifikanzgrenze in beiden Rassen. Somit bestätigt diese Studie den Einfluss des proximalen Abschnittes von BTA1 auf das Temperament bei Mutterkuhkälbern.

Schlüsselwörter: BTA1, Mikrosatelliten, Temperament, Hornstatus, Fleischrind, Kälber

\section{Introduction}

QTL-studies with beef cattle are limited although their importance is increasing. In beef cattle the temperament and behaviour of the animals is very important; for the safety and welfare of the animals and for the safety of the farmer (GRANDIN 1993). The temperament also influences the daily gain of cattle and such with calmer temperament show higher gains than nervous cattle (VOISINET et al. 1997). Also the feeding duration and temperament is genetically correlated (NKRUMAH et al. 2007).

A genetic background of temperament is known and the estimated heritabilities of temperament in different tests ranged between 0.0 and 0.33 in German Angus and German Simmental (GAULY et al. 2002). In Hereford and Simmental a heritability of 0.03 (HEARNSHAW and MORRIS 1984) and in beef cattle crosses of 0.49 (NKRUMAH et al. 2007) are described.

One earlier study with suckler cows measured temperament in Canadian Beef Cattle electronically as movements in isolation of fellows (SCHMUTZ et al. 2001). They described among others a QTL on BTA1 near BMS574 for temperament and habituation.

This study was conducted to verify this QTL and analyse the proximal region of BTA1 for the importance for behaviour in beef cattle calves.

\section{Material and methods}

The temperament of purebred German Angus and German Simmental calves was scored in three different testing situations. The calves were born in four consecutive years and reared at the Experimental Farm Rudlos of the University Giessen. All together, 962 calves descending from six German Angus sires (545 calves) and eight German Simmental sires (417 calves) respectively were evaluated. At three weeks of age the first test, a tethering test (BOISSY and BOUISSOU 1988), was done. The calves were fixated with a headstall and their behaviour after two minutes fixation scored (score TT). The second test was a weighing test (TULLOH 1961) with a commonly used weighing machine at five month of age. The calves were scored while entering the scale (score WT1) and during the weighing process (score WT2). At the age of seven to eight month a separation- and restraint test (LE NEINDRE et al. 1995) was done and scored as described in GAULY et al. (2001) (score ST). The scores ranged from 1=calm to $5=$ very excited and nervous. The distribution of the scores is shown in Table 1. In German Simmental $47.86 \%$ of the calves were polled, $34.51 \%$ were horned and $17.63 \%$ had scurs. 
Table 1

Distribution of the assigned values (1-5) of the scores of tethering test (TT), weighing test (WT1 and WT2) and separation- and restraint test (ST) in percent for German Angus (GA) and German Simmental (GS) calves Verteilung der Bewertungen (1-5) der Scores für den Anbindetest (TT), Wiegetest (WT1 und WT2) und Separier- und Rückhaltetest (ST) in Prozent bei Deutsche Angus (GA) und Deutsches Fleckvieh (GS) Kälbern

\begin{tabular}{lcccccc}
\hline & & 1 & 2 & 3 & 4 & 5 \\
\hline TT & GA & 39.46 & 35.01 & 12.77 & 11.80 & 0.97 \\
& GS & 35.25 & 41.25 & 11.75 & 11.23 & 0.52 \\
& GA & 54.67 & 16.76 & 11.43 & 14.86 & 2.29 \\
WT2 & GS & 54.08 & 14.80 & 11.73 & 17.09 & 2.30 \\
& GA & 16.22 & 38.17 & 34.92 & 8.97 & 1.72 \\
ST & GS & 11.03 & 37.44 & 35.38 & 14.10 & 2.05 \\
& GA & 18.62 & 47.41 & 25.91 & 7.87 & 0.19 \\
& GS & 15.31 & 42.60 & 30.61 & 8.93 & 2.55 \\
\hline
\end{tabular}

All calves were genotyped for BMS574 and in addition two microsatellites proximal (INRA117, DIK634) and distal (BMS4020, DIK4957) each on the basis of the MARC USDA cattle genome map. In a first analysis INRA117 was detected to be monomorphic and replaced by BMS1928. One duplex-PCR with BMS4020 and DIK4957 and single PCRs for the other microsatellites were established. The microsatellites were analysed at the ALF express (Amersham Bioscience) under standard conditions and alleles were scored with the program AlleleLocator version 1.03. The statistical analysis was done with SAS version 8.01 separated by breeds. In the variance analysis sex and year were included as fixed effects and the sire as random effect. In German Simmental the status horned or polled (with scurs belonging to polled) was used as additional fixed effect. As covariate the age at test was used. For the estimation of allele substitution effects the analysis was done for each microsatellite separately. The allele with the highest frequency per breed was set as standard allele (HOH and OTT 2001) and for all other alleles with a frequency of more than $5 \%$ the number of alleles for each animal $(0,1$ or 2$)$ was used as covariate in a linear model. The significance threshold of $5 \%$ was Bonferroni-corrected.

\section{Results and discussion}

The number of alleles varied between the breeds from 2 to 16 within breeds (Table 2).

Table 2

Analysed microsatellites with position on BTA1 (MARC USDA database), number of detected alleles and allele sizes in German Angus and German Simmental

In die Analyse einbezogene Mikrosatelliten mit der Position auf BTA1 (nach der MARC USDA Datenbank), Anzahl der identifizierten Allele und Allelgrößen in den Rassen Deutsche Angus und Deutsches Fleckvieh

\begin{tabular}{|c|c|c|c|c|c|c|}
\hline \multirow[t]{2}{*}{ Microsatellite } & \multirow[b]{2}{*}{ Position } & \multicolumn{2}{|c|}{ German Angus } & \multicolumn{2}{|c|}{ German Simmental } & \multirow{2}{*}{$\begin{array}{c}\text { Total number } \\
\text { of detected } \\
\text { alleles }\end{array}$} \\
\hline & & Allele size & $\mathrm{N}$ of alleles & Allele size & $\mathrm{N}$ of alleles & \\
\hline BMS1928 & $8.48 \mathrm{cM}$ & $143-183$ & 16 & $151-183$ & 13 & 19 \\
\hline DIK634 & $10.01 \mathrm{cM}$ & $226-234$ & 4 & $228-230$ & 2 & 4 \\
\hline BMS574 & $15.43 \mathrm{cM}$ & $133-155$ & 8 & $143-153$ & 2 & 8 \\
\hline BMS4020 & $18.38 \mathrm{cM}$ & $119-121$ & 2 & $119-121$ & 2 & 2 \\
\hline DIK4957 & 20.70 cM & $184-190$ & 4 & $186-190$ & 3 & 4 \\
\hline
\end{tabular}


The frequencies of alleles ranged from one percent up to $99 \%$ with great differences between the breeds. For example the allele BMS1928 (145) with $15.7 \%$ frequency in German Angus which was not shown in German Simmental. On the other hand the allele BMS1928 (163) is in German Simmental (29.08\%) tenfold frequently than in German Angus (2.89\%). The standard alleles are the same in both breeds namely BMS1928 (161), DIK634 (230), BMS574 (149), BMS4020 (121) and DIK4957 (186).

In German Angus four alleles of BMS1928 (145, 157, 159 and 183) and in German Simmental three other alleles $(163,167$ and 169) were tested. For DIK634 two alleles in German Angus (228 and 234) and one of these in German Simmental (228) were included in the analysis. For the other three microsatellites the same alleles were tested in both breeds, namely four for BMS574 (143, 147, 151 and 153) and one for BMS4020 (119) and DIK4957 (188) each.

The allele 169 of $B M S 1928$ had a significant effect on score WT2 in German Simmental with a $P$-value of 0.0078 ( $5 \%$-threshold $P=0.016)$. Close to the $5 \%$-threshold $(P=0.0125)$ was the BMS574 allele 153 with $P=0.0178$ for score ST in German Simmental. The same allele is also in German Angus close to the $5 \%$-threshold with score WT2 and a $P$-value of 0.0128 .

The result is indicating that the important region of BTA1 concerning behaviour of calves is the proximal end above $15 \mathrm{cM}$. This validated the results of SCHMUTZ et al. (2001) although the behaviour tests and breeds analysed were different. In a recently published QTL-study the microsatellite $B M 6438$ located at $1.781 \mathrm{cM}$ showed a significant influence on habituation in two social separation tests (GUTIÉRREZ-GIL et al. 2008). In addition the polled locus, located in proximal region of BTA1 (GEORGES et al. 1993, SCHMUTZ et al. 1995, DRÖGEMÜLLER et al. 2005), is discussed to influence the behaviour of animals. With status of horn included in the model of German Simmental a significant effect of the most proximal microsatellite was proven. Furthermore a difference in allele-frequencies between a polled breed (German Angus) and a breed with polled and horned animals (German Simmental) was shown. So we delivered with this study another point for the importance of the proximal part of BTA1 in cattle behaviour and this region should be kept clearly in mind.

\section{Acknowledgements}

We thank Holger Mathiak, Carina Urban and the staff at the Rudlos Experimental Farm for conducting the behaviour tests. This work was financially supported by the German Research Foundation within SFB299.

\section{References}

Boissy A, Bouissou MF (1988) Effects of early handling on heifer's subsequent reactivity to humans and to unfamiliar situations. Appl Anim Behav Sci 20, 259-73

Drögemüller C, Wöhlke A, Mömke S, Distl O (2005) Fine mapping of the polled locus to a 1-Mb region on bovine chromosome 1q12. Mamm Genome 16, 613-20

Gauly M, Mathiak H, Erhardt G (2002) Genetic background of behavioural and plasma cortisol response to repeated short-term separation and tethering of beef calves. J Anim Breed Genet 119, 379-84

Gauly M, Mathiak H, Hoffmann K, Kraus M, Erhardt G (2001) Estimating genetic variability in temperamental traits in German Angus and German Simmental cattle. Appl Anim Behav Sci 74, 109-19 
Georges M, Drinkwater R, King T, Mishra A, Moore SS, Nielsen D, Sargeant LS, Sorensen A, Steele MR, Zhao X, Womack JE, Hetzel J (1993) Microsatellite mapping of a gene affecting horn development in Bos taurus. Nat Genet 4, 206-10

Grandin T (1993) Behavioral agitation during handling of cattle is persistent over time. Appl Anim Behav Sci $36,1-9$

Gutiérrez-Gil B, Ball N, Burton D, Haskell M, Williams JL, Wiener P (2008) Identification of quantitative trait loci affecting cattle temperament. J Hered 99, 629-38

Hearnshaw H, Morris CA (1984) Genetic and environmental effects on a temperament score in beef cattle. Aust J Agric Res 35, 723-33

Hoh J, Ott J (2001) A train of thoughts on gene mapping. Theor Popul Biol 60, 149-53

Le Neindre P, Trillat G, Sapa J, Menissier F, Bonnet JN, Chupin JM (1995) Individual differences in docility in limousin cattle. J Anim Sci 73, 2249-53

Nkrumah JD, Crews DH Jr, Basarab JA, Price MA, Okine EK, Wang Z, LiC, Moore SS (2007) Genetic and phenotypic relationships of feeding behavior and temperament with performance, feed efficiency, ultrasound, and carcass merit of beef cattle. J Anim Sci 85, 2382-90

Schmutz SM, Marquess FL, Berryere TG, Moker JS (1995) DNA marker-assisted selection of the polled condition in Charolais cattle. Mamm Genome 6, 710-3

Schmutz SM, Stookey JM, Winkelman-Sim DC, Waltz CS, Plante Y, Buchanan FC (2001) A QTL study of cattle behavioral traits in embryo transfer families. J Hered 92, 290-2

Tulloh NM (1961) Behaviour of cattle in yards. I. Weighing, order and behaviour before entering scales. Anim Behav 9, 25-30

Voisinet BD, Grandin T, Tatum JD, O'connor SF, Struthers JJ (1997) Feedlot cattle with calm temperaments have higher average daily gains than cattle with excitable temperaments. J Anim Sci 75, 892-6

Received 10 June 2009, accepted 18 January 2010.

Corresponding author:

GEORG ERHARDT

email: georg.erhardt@agrar.uni-giessen.de

Department of Animal Breeding and Genetics, Justus-Liebig-University of Giessen, Ludwigstr. 21 B, 35390 Giessen, Germany 